\title{
Late Cretaceous-Paleogene Formation of the Bekrit Syncline, Middle Atlas, Morocco: Sedimentology, Geochemistry, Palynology and Paleoenvironments
}

\author{
Mohammed El Attmani ${ }^{*}$, Amine Bouwafoud1', Salem Elouariti' ${ }^{1}$ Hicham Si Mhamdi², \\ Abdelmajid Ben Bouziane1, Mustapha Mouflih1
}

${ }^{1}$ Sedimentary Basins Dynamic and Geological Correlations Laboratory, Department of Geology, Faculty of Science Ben M'sik, Hassan II University of Casablanca, Casablanca, Morocco

${ }^{2}$ Laboratory of Applied Geology, Department of Geosciences, Faculty of Sciences and Techniques Errachidia, Moulay Ismail University of Meknes, Meknes, Morocco

Email: *elattmanim@gmail.com

How to cite this paper: El Attmani, M., Bouwafoud, A., Elouariti, S., Si Mhamdi, H., Bouziane, A.B. and Mouflih, M. (2021) Late Cretaceous-Paleogene Formation of the Bekrit Syncline, Middle Atlas, Morocco: Sedimentology, Geochemistry, Palynology and Paleoenvironments. Open Journal of Geology, 11, 61-80.

https://doi.org/10.4236/ojg.2021.113005

Received: August 31, 2019

Accepted: March 20, 2021

Published: March 23, 2021

Copyright $\odot 2021$ by author(s) and Scientific Research Publishing Inc. This work is licensed under the Creative Commons Attribution-NonCommercial International License (CC BY-NC 4.0). http://creativecommons.org/licenses/by-nc/4.0/ (c) (i) (8) Open Access

\begin{abstract}
Globally, the Paleogene period experienced several events marking the Paleocene-Eocene transition which is especially to one of the hottest periods that the Earth has ever known (Paleocene-Eocene Thermal Maximum, PETM), followed by the biological crisis that affected benthic foraminifera. The Bekrit Syncline, subject of this study, shows three Formations of range from the Cretaceous to the Eocene ages (the El Koubbat, Irbzer and Bekrit-Timahdite Formations). Sedimentological, palynological and geochemical analyses of collected samples, in the Bekrit syncline, were studied to determine the paleogeographic and paleoenvironmental conditions of the Middle Atlas. The carbonate rocks were analyzed by microscopic study and geochemical analysis by X-ray Fluorescence (XF) and Inductively Coupled Plasma Spectrometry (ICP). The results obtained highlight the sedimentary events that took place during the Paleogene. Thus, the Maastrichtian is characterized by a closed euxinic marine environment shared by a more open and oxidizing environment. On the other hand, the Paleocene was a restricted marine environment with evaporitic sedimentation, while the Eocene sees the installation of a carbonate platform with a bioclastic Shoal.
\end{abstract}

\section{Keywords}

Geochemistry, Sedimentology, Palynology, Carbonates, Phosphate, Paleoenvironments, Middle-Atlas 


\section{Introduction}

The Meso-cenozoic deposits of the Moroccan Middle Atlas correspond to a shallow shelf marine environment [1] [2]. Several periods with carbonate sedimentation have been recognized in the Middle Atlas and High Moulouya: at the level of the Lower and Middle Lias in the Lower Toarcian-Bajocian, Lower Bathonian-Callovian, Upper Cretaceous and Eocene [3]-[12].

The Paleogene, the subject of this study, represented an important period of geological history on the scale of the Earth. This period shelters the KT (Cretaceous-Tertiary) crisis and the climatic crisis of the Paleocene-Eocene transition. The latter is responsible for global warming of the Earth $\left(\approx+5^{\circ} \mathrm{C}\right)$, global change in the ocean circulation pattern and also for the quick extinction of benthic Foraminifera [13]. This crisis is known among scientists by the name "PETM" (Paleocene Eocene Thermal Maximum).

The study of these events has awake the interest of the international scientific community for several decades on the KT crisis [14] [15] [16] [17] [18], and the work on the Paleocene-Eocene Thermal Maximum (PETM) [12] [19]-[24].

In Morocco, the late Cretaceous-Paleogene series are marked by the deposition of the most important phosphate basins in the world (Oulad Abdoun, El Gantour, Meskala and Oued Dahab). The Mesetian phosphate basins as a whole are characterized by the deposition of two bio-sedimentary systems with very distinct characteristics: a lower bio-sedimentary system of Campanian-Maastrichtian age, and a higher bio-sedimentary system of Palaeogene area. They are separated by a significant sedimentary boundary of regional extension of SB1 type [25]-[31].

Besides these phosphate basins, the Moroccan subsoil has other phosphate basins of lesser economic interest, such as the residual deposits of the Middle Atlas and the High Atlas of Marrakech. On the northern slope of the High Atlas, the sedimentary series of Late Cretaceous-Paleogene age are characterized by shallow marine deposits, of marginal-littoral to epicontinental (subtidal to inter-supratidal) type, which mainly carbonates (limestone, dolomites and marls) but also phosphates and detritus [27]. These series are subdivided into two sedimentary systems, separated by a sedimentary discontinuity (SB1 type sequence boundary) that results in a hardened, karstified, locally silicified and perforated surface [25].

At the level of phosphate occurrences in the Middle Atlas, sequence stratigraphy has defined two sedimentary systems separated by a sedimentary boundary of SB1, with supra-regional values identifiable at the Foum Khneeg region and comparable to those of the Moroccan Meseta basins [31]. This series at the level of the residual basins of the South-Western Middle Atlas reflect bitumino-phosphate and carbonate sedimentation very rich in fauna, flora and consequent geological events [31] [32].

The objective of this study is to define all the stages of phosphate, bituminous and carbonate sedimentation of the Bekrit syncline (El Koubbat syncline); to provide the main features of all the paleogeographic and paleoclimatic events at the Cretaceous-Tertiary (K-T) and PETM transitions, on the basis of geochemi- 
cal, sedimentological and Palynological analyses.

\section{Geological Setting}

The Middle Atlas is a mountain chain oriented NE-SW, stretching over more than $400 \mathrm{~km}$ from the central high Atlas in the south to the first hills of the Rifain region in the north (Figure 1). It is boarded the east by the eastern Moroccan Meseta, and the west by the western Moroccan Meseta. The Middle Atlas is subdivided into two sub-domains separated by Oued Srou: the Northern Middle Atlas to the NE and the Southern Middle Atlas to the SW [33] which is adjacent to the Central High Atlas with which is structurally inseparable [34].

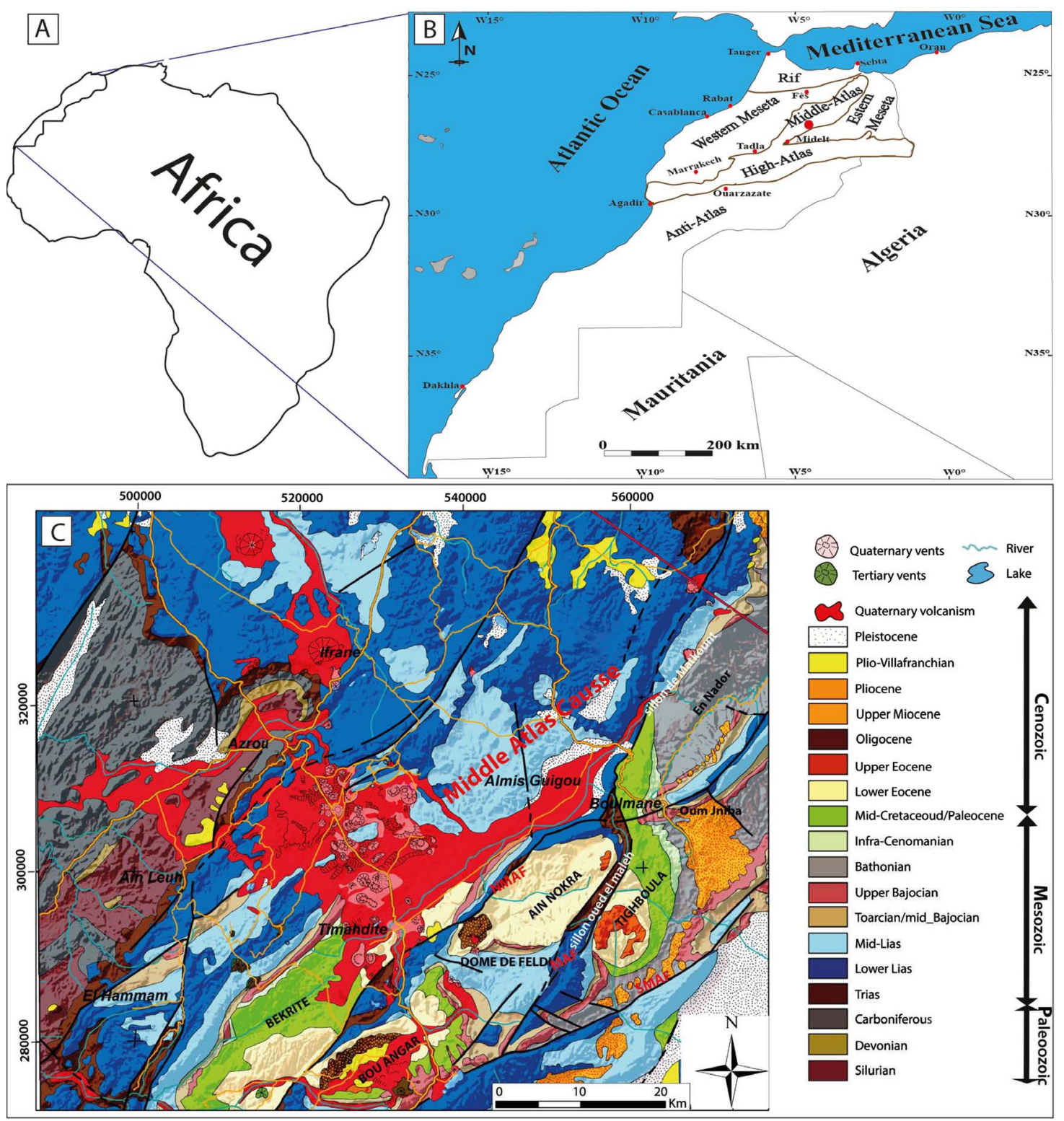

Figure 1. Geographical location from Morocco to the African continent (A), the location of the Middle Atlas in the Moroccan Atlas domain (B), Geological map of the folded Middle Atlas according to Mountaj et al. (2019) (C) [38]. 
The work conducted by Termier (1936) [35] in the Middle Atlas permits to subdivide it into two sub-domains separated by the North Middle Atlas Fault Zone (NMAFZ); the Middle Atlas Causse in the North-West and the Folded Middle Atlas in the South-East. The NMAFZ corresponds to the first anticline ride of Colo (1961-1964) [36]. It is underlined by a sinuous crest line, oriented approximately NE-SW. from the North-East to the South-West we distinguish: Jbel Tajda, Jbel Ben Ij, Jbel Tisdadine, Foum Khneeg and Jbel Hayane. Its most obvious materialization is of a morphological order [8] [37]:

- The Middle Atlas Causse, or tabular Middle Atlas, with altitudes ranging from 1400 to 2000 meters in the form of plateaus cut into fault blocks along several north-east facing faults. This sub-domain is formed by Liasic carbonate cobred by Plio-quaternary basalt flows from many volcans [38] [39] [40] [41] [42].

- The folded Middle Atlas corresponds to the reliefs forming High Mountain exceeding $3340 \mathrm{~m}$ in altitude. Structurally, it is marked by the existence of anticline Colo wrinkles [36], which form the main relief lines. These anticline wrinkles are separated by large synclines of Bekrit-Timahdite, BouAnguer, Ain Nokra and Odikssou, home to a thick Jurassic sedimentation, covered by the Cretaceous-Paleogene sedimentation (Figure 2).

- Most of the Middle Atlas is covered by carbonate sedimentation of limestone, marls and marine dolomites from the Lower and Middle Jurassic which cover red Permian and Triasic detritic sedimentation. Deposits from the shallow continental sea layers were deposited during the Cretaceous to the Tertiary [37].

Since the beginning of the Mesozoic, the structural history of the Middle Atlas has been determined by a network of pre-existing faults that have been reactivated on various occasions and in various ways (Figure 1). This network of faults is characterized by a main direction from $35^{\circ}$ to $45^{\circ}$ [43] [44].

Meso-cenozoic sedimentation deposited without major discontinuity in the history of the Middle Atlas [4].

The Mesozoic of the Middle Atlas outcrops in the residual basins. It begins with red detritus deposits with evaporitic interleavings accompanied by the establishment of a fissured and explosive volcanism of the Triassic [5] [45]. The latter is covered by carbonate deposits recognized in the residual basins as a platform deposit materialized by dolomitic deposits of Sebkha in the lower Lias, followed by a carbonate deposit that evolves from a closed environment to an open environment in the upper Lias. The Dogger rests in concordance on the Lias is marked by deposits of reef limestones following the grey marls, covered by red marls topped by deposits of clay and evaporite marls that evolve to a terrific sedimentation [2] [10] [37] [46].

The Cretaceous is based in discordance on the terrific sedimentation of the Dogger. It begins with carbonate sedimentation, followed by conglomerates covered with limestone and marl and ends with conglomerates from the Oued EL 
Atchane of the lower Cretaceous [5]. The Upper Cretaceous is marked by bituminous and phosphate sedimentation in the El Koubbat Formation, followed by red sandstones of Ait Hamza and marls of Tighboula, surmounted by marl limestone deposits and limited by gypsum marls [1] [2] [4] [37] [47] [48].

The Cenozoic has red sandstones in the basal area and red marls with evaporitic interleaved marls delivering Feistiella Charophytaes indicate a Maastrichtian-Paleocene age that is located in the Bekrit-Timahdite residual basin (Irbzer Formation), Ain Nokra, Oudikessou and BouAnguer, surmounted by bioclastic limestones of the Bekrit-Timahdite Formation, pink, yellow to white, shallow sea of middle Eocene age. These limestones are overcome by a regressive series of post-Lutetian gypsum red marls from the Feleddi Formation, a Oligocene age continental sandstone conglomerate series and Miocene lake deposits [2] [3] [49].

During the Plio-quaternary period, the Middle Atlas was the site of alkaline magmatic activity (Figure 1). They recognized two alkaline series of Middle Miocene and Middle Quaternary ages [39] [40] [41] [42].

The Late Cretaceous-Paleogene Formations range laterally across the four synclines (Figure 2). In the Bekrit syncline, the Paleogene deposits lie concordantly on the Upper Cretaceous. The Upper Cretaceous consists of five Formations, of which the El Koubbat Formation is represented only in the Bekrit Syncline. On the other hand, the Bou Angueur Syncline represents Cretaceous and Paleogene deposits beginning with the Foum Kheneg Formation, which lies in angular discordance on Middle Jurassic limestone and dolomite limestone. This Formation represents the equivalent of the Irbzer Formation which is not outcropping in the Bou Angueur Syncline. It is surmounted by the Bekrit-Timahdite, Felledi and Oudiksou Formations.

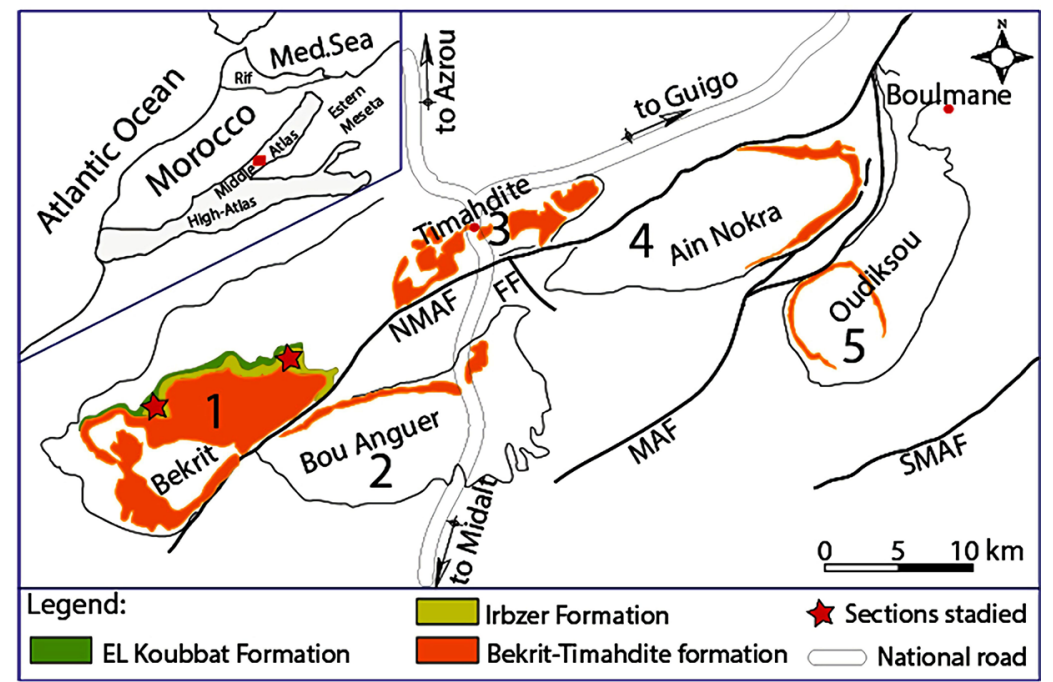

Figure 2. Schematic map of the south-western part of the Middle Atlas. Bekrit Syncline (El Koubbat Syncline) (1), Bou Anguer Syncline (2), Timahdite Syncline (3), Ain Nokra Syncline (4), Oudiksou Syncline (5), Felledi Fault (FF), Northern Middle Atlas Fault (NMAF), Middle Atlas Fault (MAF), Southern Middle Atlas Fault (SMAF). 
The reactivation of major faults plays a very important role in the Tertiary sedimentation identifying a different stratigraphy on either side of the fault. It separates a domain with a Cretaceous series and a domain devoid of the Cretaceous series [1] [2] [4] [8] [38] [50] [51].

\section{Materials and Methods}

This study is based on a set of carbonate, phosphate and bituminous rock samples that were collected in the Tasemakt section, on the northeast flank of the Bekrit syncline (EL Koubbat syncline). The selected samples underwent a thinsection petrographic study using a Nikon polarizing microscope at a magnification ranging from $40 \mu \mathrm{m}$ to $400 \mu \mathrm{m}$ and microphotographs were taken with a Canon camera. For the description of thin sections and the identification of microfacies the following books have been used: Flügel (2010) [52]. The classification used is that of Dunham (1962) [53] completed by Embry \& Klovan (1972) [54].

Geochemical analyses focused on a set of representative carbonate samples from the Tasemakt section (Bekrit Syncline). The geochemical analyses, carried out by inductively coupled plasma spectrometry (ICP) and X-ray fluorescence, mainly concerned carbonate facies of Eocene age at the National Center for Scientific and Technical Research (N.C.S.T.R) and Sedimentary Basins Dynamics and Geological Correlations Laboratory, Faculty of Sciences Ben M'Sik, Casablanca).

For X-ray fluorescence, the wavelength dispersion spectrometer-type Axios is used. The pastil (PROT-ELE03-v01) and the bead (PROT-ELE02-v01) are used by ignition measured by heating the samples to $1000 \mathrm{C}^{\circ}$ in porcelain crucibles.

The statistical study by principal component analysis (PCR) was carried out on a table of Individuals according to 10 variables. The variables used are: Iron, Chromium, Potassium, Magnesium, Manganese, Sodium, Nickel, Phosphorus, Strontium and Zinc.

The palynological analysis adopted is the one used to process Tertiary age samples (Slimani, unpublished report). The protocol used for palynological analysis corresponds to an optimized extraction of Dinokysts and pollen grains on the sedimentary fraction $<250 \mu \mathrm{m}$. The aim of palynological attack is to free organic matter from the mineral matrix that surrounds it. The samples represent clays, sandstone clays, sandstones, marls and carbonates. This technique is carried out in the laboratory of sedimentary basin dynamics and geological correlations.

\section{Results and Discussions}

\subsection{Sedimentological Analysis}

\subsubsection{Sedimentary Corteges}

The raised sections are located on the northwestern flank of the El Koubbat syncline in the vicinity of the Tasemakt oil shale heat treatment pilot plant. The se- 
dimentological and sequences interpretation allow the definition of five deposit sequences (Figure 3 \& Figure 4).

The Deposit Sequence A, of Maastrichtian area, begins with an alternation of 20 meters of bedded and indurate marls in fine platelets evolving into bituminous, very oily and dolomitic black shells. The thin limestones are Wackstone/Packstone textures with benthic Foraminifera, rare phosphate grains, rare quartz grains and dolomicrite to dolomicrosparite matrix. This succession is surmounted by alternating brown marly limestones with phosphate bioclasts.

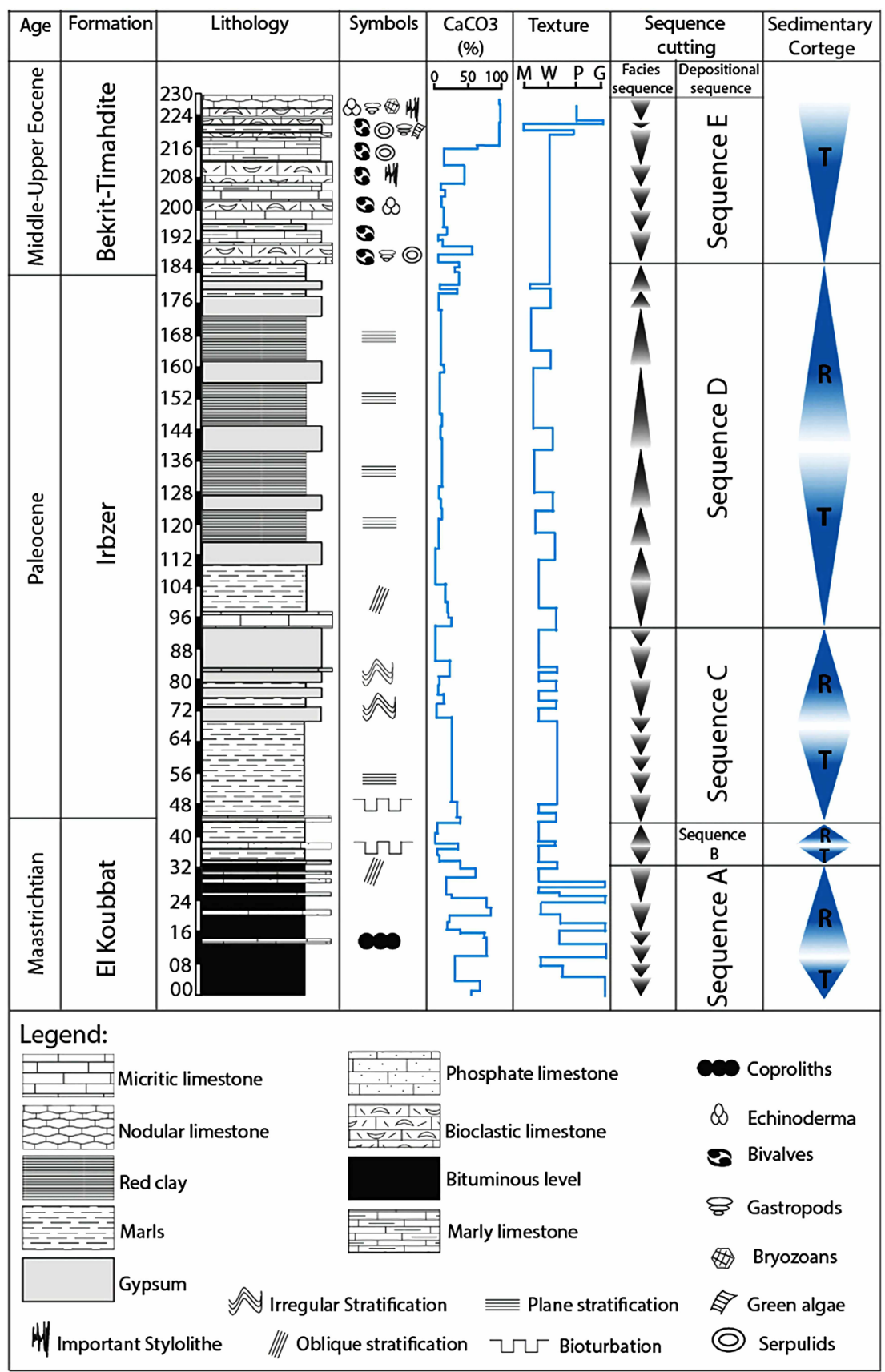

Figure 3. Sequence cutting of the Late Cretaceous-Paleogene series of the Tasemakt section, Bekrit syncline, Middle Atlas (Morocco). 


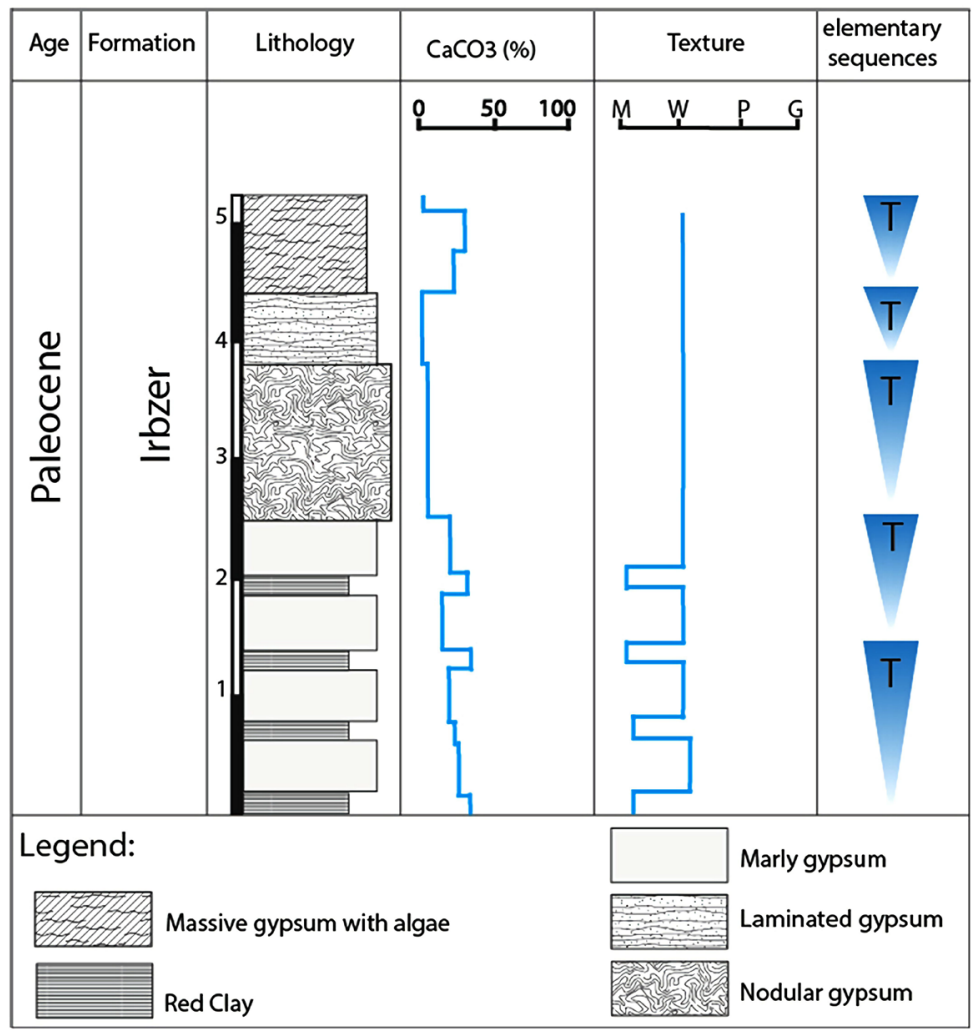

Figure 4. Elementary parasequence of gypsum facies, in the Irbzer Formation, Middle Atlas (Morocco).

The Deposit sequence B, which is Maastrichtian-Paleocene age, is formed globally by two facies sequences. The base of the sequence is underlined by brown micritic siliceous limestones and greenish bituminous marls with phosphate debris.

The Deposit Sequence C, which Paleocene area, consists more than 50 meters thick facies sequences interpreting a transgression cortege. The latter represents an alternation of yellow marls with calcitic concretions and green marls slightly gypsum. The high sea level deposits are 58 meters thick and mark a global trend of relative sea level decrease. These deposits are composed of a succession of elementary parasequences reflecting an alternation of clay and gypsum facies that characterizes an accumulation of marine floods of low water level (Figure 4). The regressive trend is marked by the stratocrogression of gypsum facies in privilege of clay facies.

The deposit sequence D, which Lowers Paleocene-Eocene age, is heralded by a transgressive surface represented by lightly phosphated limestones with distinct bioturbation. The set of facies sequences records a thickness of about 200 meters and translates into a remarkable similarity and stability of sedimentation rhythms. Such a scenario underlines an aggrading sedimentary dynamic despite the low water levels and the influence of continental inputs of the Paleocene period. The maximum flooding surfaces (MFS) are underlined by some levels of blackish marls that do not exceed 0.5 meters in thickness. 
The deposit sequence E, of Lower Eocene-Upper Eocene age, is expressed by consolidated marls and yellow limestones. It heralds the installation of a carbonate sedimentation platform increasingly rich in marine fauna and marine flora (Figure 5).

\subsubsection{Microfacies Analysis}

The microfacies family's found in the two sections of the El Koubbat syncline are compiled into four microfacies families (Figure 5 \& Figure 6):

- Microfacies family I: This family is marked by the richness of the bioclasts and lithoclasts which plunge into a micritic matrix. This is the complex of biomicritical limestones that have a Packstone texture. Sometimes, some microfacies show binder heterogeneity with the appearance of sparite or microsparite patches that herald secondary recrystallization. This family is characterized by a varied faunal assemblage, one site in order of importance: Bryozoans, Green Algae, Gastropods, Annelids and Milliolids.
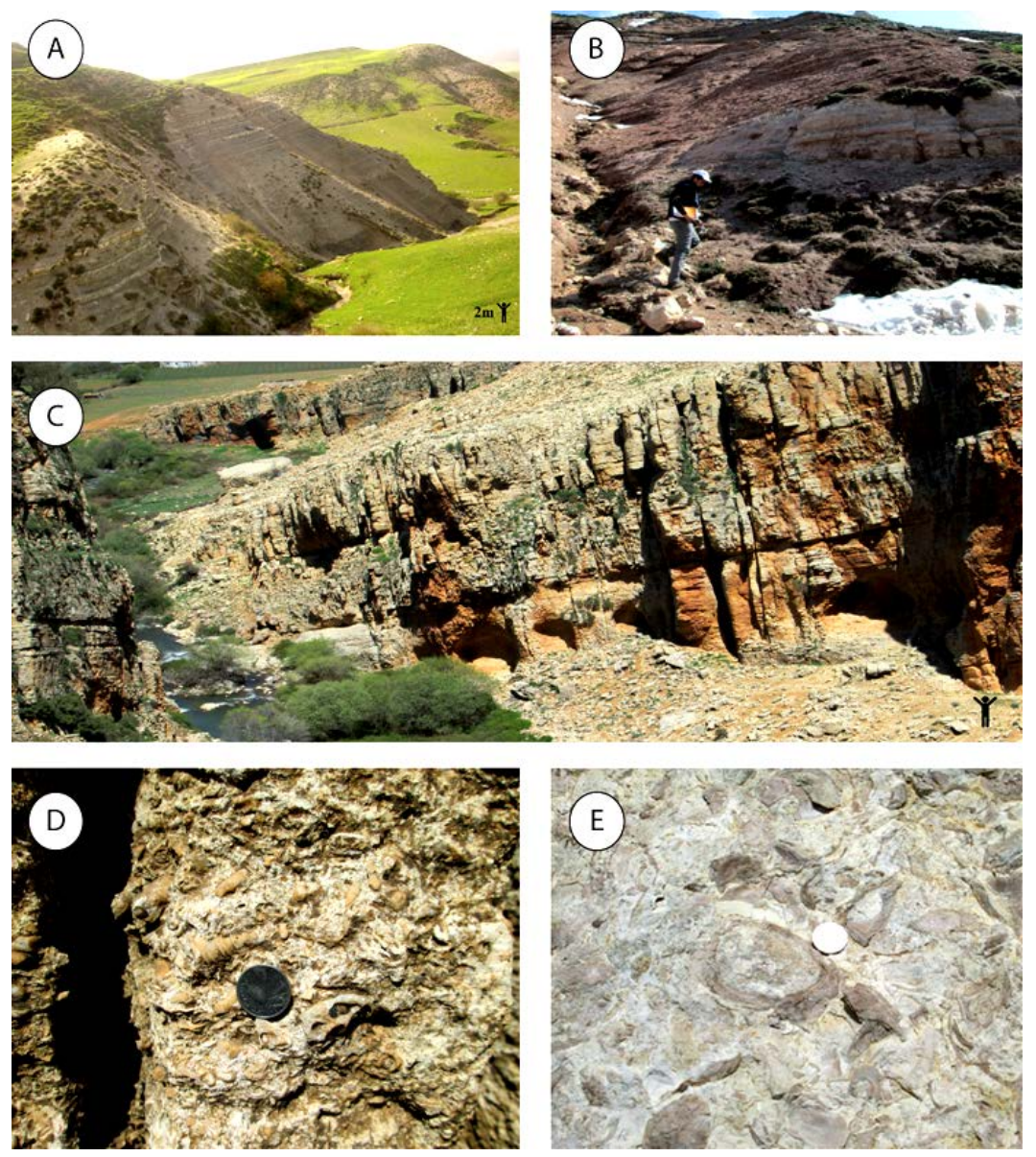

Figure 5. The Tassemakt section shows the alternation of calcareous (light) and bituminous (dark) banks (A), the passage between the alternation of marls and gypsum at the base and the alternation of red clay and massive gypsum levels in the Irbzer Formation (B); the Bekrit Formation is characterized by the alternation of massive limestone at the top and nodular at the base (C), Fossiliferous limestone rich in Gastropods (D), Fossiliferous limestone rich in oyster $(\mathrm{E})$. 

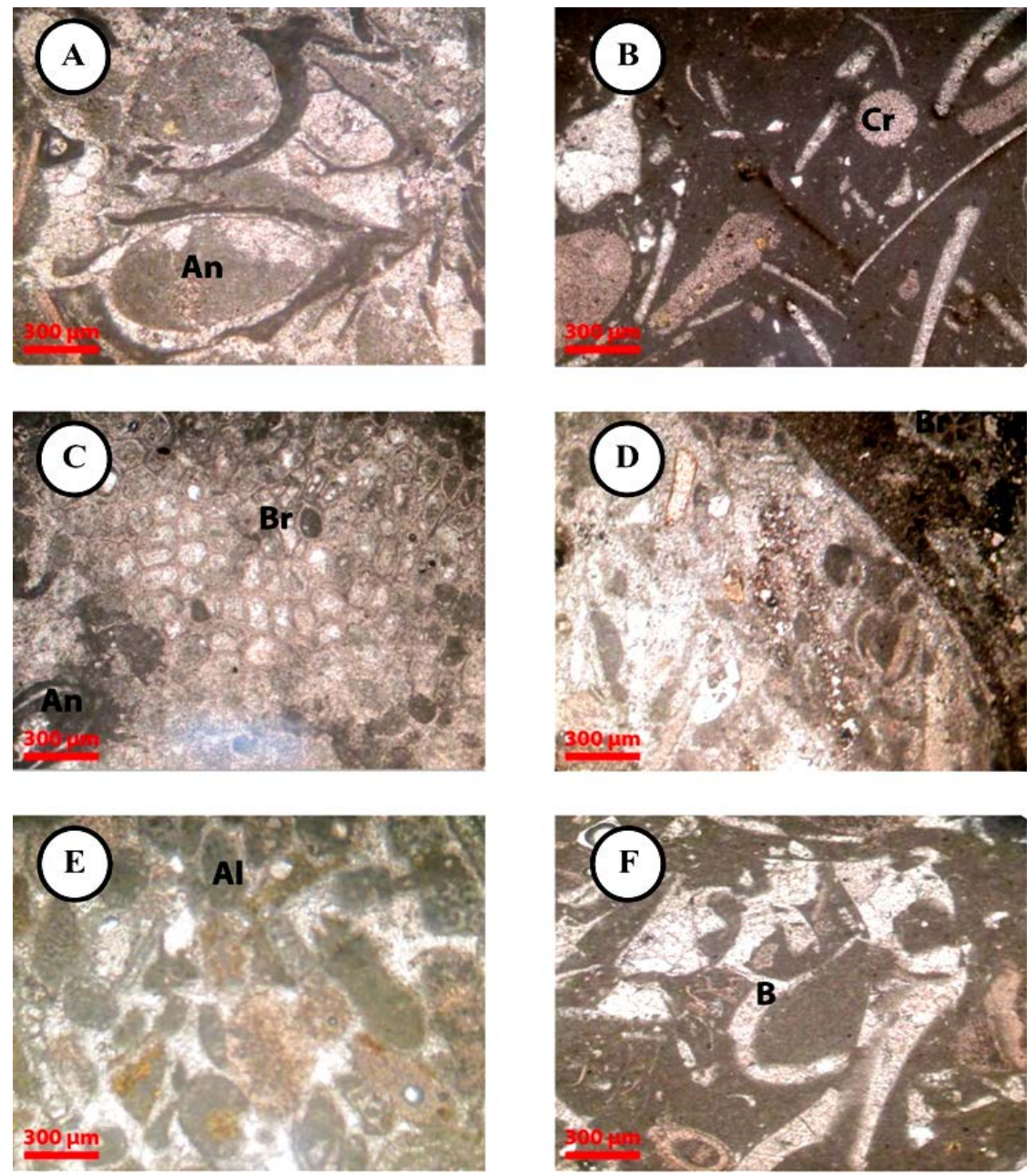

Figure 6. Carbonate microfacies of Eocene age of the Bekrit Formation, Biomicrite with packstone texture rich in Serpulidae (A), Biomicrite with wackstone texture rich in biogenic debris and crinoid plates (B), Biomicrite with packstone texture showing bryozoan incrustations (C), Reworked microfacies rich in detrital inputs and fractured bioclast debris (D), Packstone-textured biosparite with abundance of green algae (Halimeda) (E), Packstone-textured biomicrite rich in biogenic debris (F). Serpulidae (An); Green algae (Al); Bryozoaire (Br); Crinoid (Cr); Bioclasts (B).

- Microfacies family II: This family includes biomicrite-like microfacies with bioclastic debris and Wackstone texture. It is characterized by a faunal assemblage of the type: Bryozoans, fragments of Lamellibranches (sometimes ornamented), Crinoids and small biogenic debris.

- Microfacies family III: This family is represented by microfacies with a sparite binding phase and skeletal figurative elements such as green algae, bryozoans and gastropods. They are Biosparits with Grainstone texture.

- Microfacies family IV: This association reflects the sparitic microfacies with dominance of bioclasts and/or intraclasts. These are microfacies characterized by reworked elements and bioclastic debris of large size broken and reworking indices. The wildlife content includes the following bioclasts: fragments of Bryozoans, Lamellibranchs, Gastropods and Crinoids. 


\subsection{Paleodepositional Model of the Bekrit Syncline}

The study of the carbonate facies of the Bekrit Syncline revealed four family's of microfacies. The general distribution of these carbonate facies is characterized by a zone ranging from coastal to high barrier energy environments. Figure 7 interprets the location of all the microfacies families inventoried according to their textures and faunal and floral associations.

\subsection{Palynofacies of Bekrit Syncline}

The Irbzer Formation is characterized by the abundance of amorphous organic matter $(80 \%)$, the absence of palynomorphs of continental origin with rare dinoflagellate cysts (Figure 8). This absence testifies to a frank marine environment slightly influenced by fine terrigenous inputs. This rarity is probably due to a reduction in photosynthesis in relation to low primary productivity due to poor light penetration, or to physico-chemical, sedimentological and diagenetic conditions that do not allow the development and conservation of dinoflagellates.

The Bekrit-Timahdite Formation is distinguished by a richer and more diversified Palynofacies with the presence of a Palynomorph of continental origin (Spores and Pollens: Cyathidites sp., Pinus sp., Podocarpidites sp.). The presence of woody organic matter and gymnosperms spores indicate some humidity of the climate and the proximity of the continent to the sedimentation environment (proximal environment).

The palynofacies of the two samples K5 and K7 from the El Koubbat Formation revealed the presence, nevertheless rare, of dinoflagellate cysts. Only the cyst $C f$. Isabelidinium cooksoniae [55] [56], is identifiable in sample K5, which would attribute the latter to Maastrichtian [57] (Figure 8).

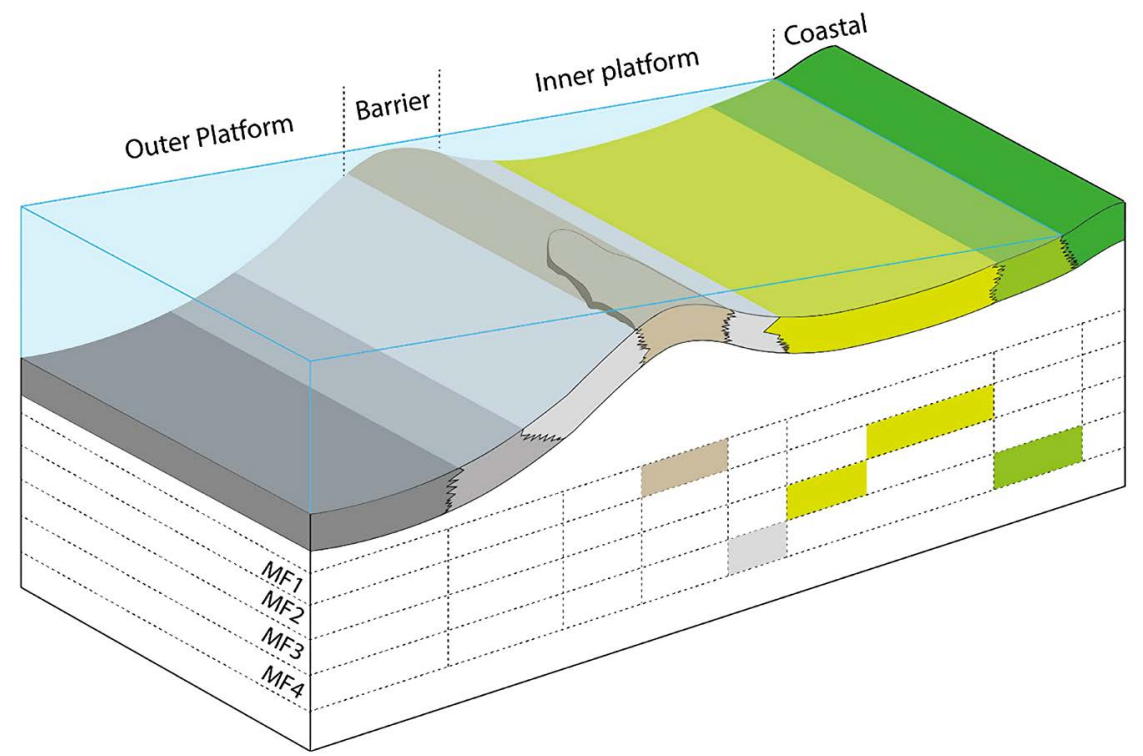

Figure 7. Depositional model showing the organization of the platform and the distribution of Microfacies Family'S (MF) identified in the Eocene. 

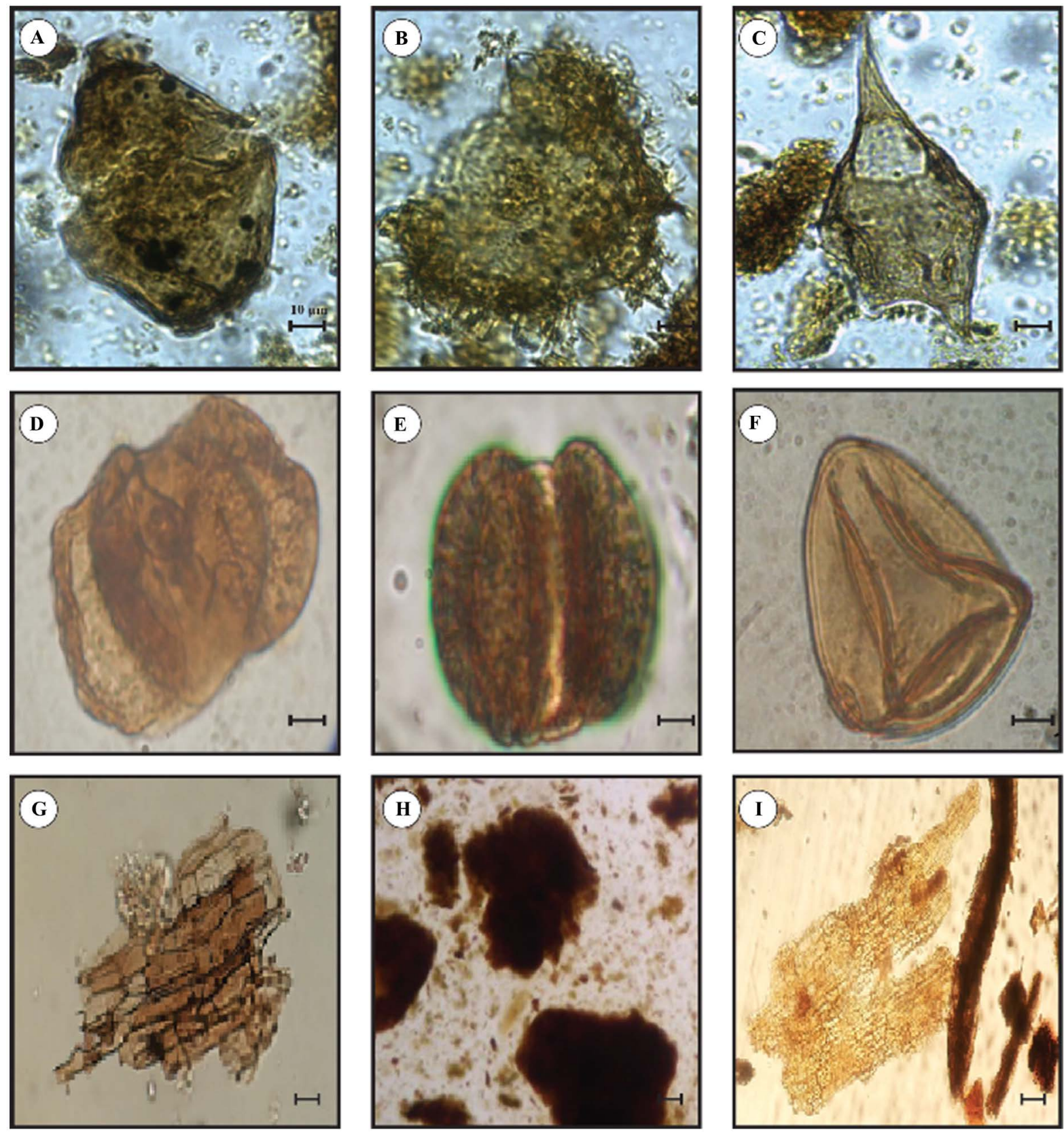

Figure 8. Carpatella cornuta (Grigorovich, 1969a), sample K7, $\times 400(\mathrm{~A})$. Areoligera senonensis (Lejeune-Carpentier, 1938a), sample K7, $\times 400$ (B). Cerodinium sp, sample K7, $\times 400$ (C). Podocarpidites sp., sample K7, $\times 400$ (D). Pinus sp., K7 sample, $\times 400$ (E). Cyathidites sp., K7 sample, $\times 400$ (F). Plant organic matter; sample K5, $\times 400$ (G). Amorphous organic matter, sample K7, $\times 400(\mathrm{H})$. Organic matter and amorphous organic matter in sample K5, $\times 400$ (I).

Despite the rather poor state of preservation of the dinoflagellate cysts contained in sample K7: Areoligera sp., Cerodinium sp. Carpatella cornuta has been identified [58] [59] and is considered a good stratigraphic marker of the Danian [60] [61].

\subsection{Geochemistry of Bekrit-Timahdite Formation}

Based on the Eocene formations, geochemical analyses show an enriching ef- 
fect of Iron, Aluminium, Magnesium, Potassium and lower concentrations of calcium. These geochemical characteristics reflect a slight drop in sea level. The higher Iron and Manganese contents testify to a maximum of chemical detritism, characterising the proximity of the continent during this period [62] [63] [64].

The increase in sea level is relatively materialized by the richness in $\mathrm{Sr}$ and the stabilization of $\mathrm{CaCO}_{3}$ compared to Iron, Aluminum, Manganese, which is becoming very low, reflecting increasingly marine environments, far from continental influences. These high contents are considered by Pomerol (1976) (in Pascal, 1985) [63] to be indirectly related to the transgression phases.

The principal component analysis allowed determining possible linkages between the samples and the chemical elements analyzed in order to facilitate the interpretation of the paleoenvironments after the crisis of the Paleocene-Eocene transition. The statistical study by principal component analysis was carried out on a table of individuals according to 10 variables. The variables used are: Iron, Chromium, Potassium, Magnesium, Manganese, Sodium, Nickel, Phosphorus, Strontium and Zinc.

The final reconstitution of the distribution of the chemical elements allowed us to define the factorial axes or factors responsible for this distribution and to highlight the affinities between the different chemical elements. This study allowed us to define three assemblies distributed in the factorial planes (F1*F2) (Figure 9):

- The first assembling, positively correlated with the factorial axes, includes Magnesium; Strontium and Manganese.

- The second, positively-negatively correlated with the factor axes, includes Iron, Chromium, Potassium and Zinc.

- The third, negatively-negatively correlated, combine's Phosphorus and Sodium.

Then, the projection of the samples allowed the definition of several components that can be distinguished according to the presence or absence of affinity between samples and assembly.

The projection of the samples allows the definition of several components (Figure 10).

The Sample T10 represents affinities with the first assembling. The increase in manganese, strontium and magnesium contents reflects a more open sea level. Pomerol (1976 in Pascal, 1985) [63] proposes that high manganese values in carbonates are indirectly related to transgression phases. Samples AG 16 and AG18 represent affinities with assembly 2.

This assemblage reflects the decline of the water slice and indicates a very proximal environment influenced by continental inputs. Samples T1A, AG13, AG20b represent affinities with Assay 3 interpreting phosphorus and sodium concentration. This configuration is probably related to a more open marine paleoenvironment. 


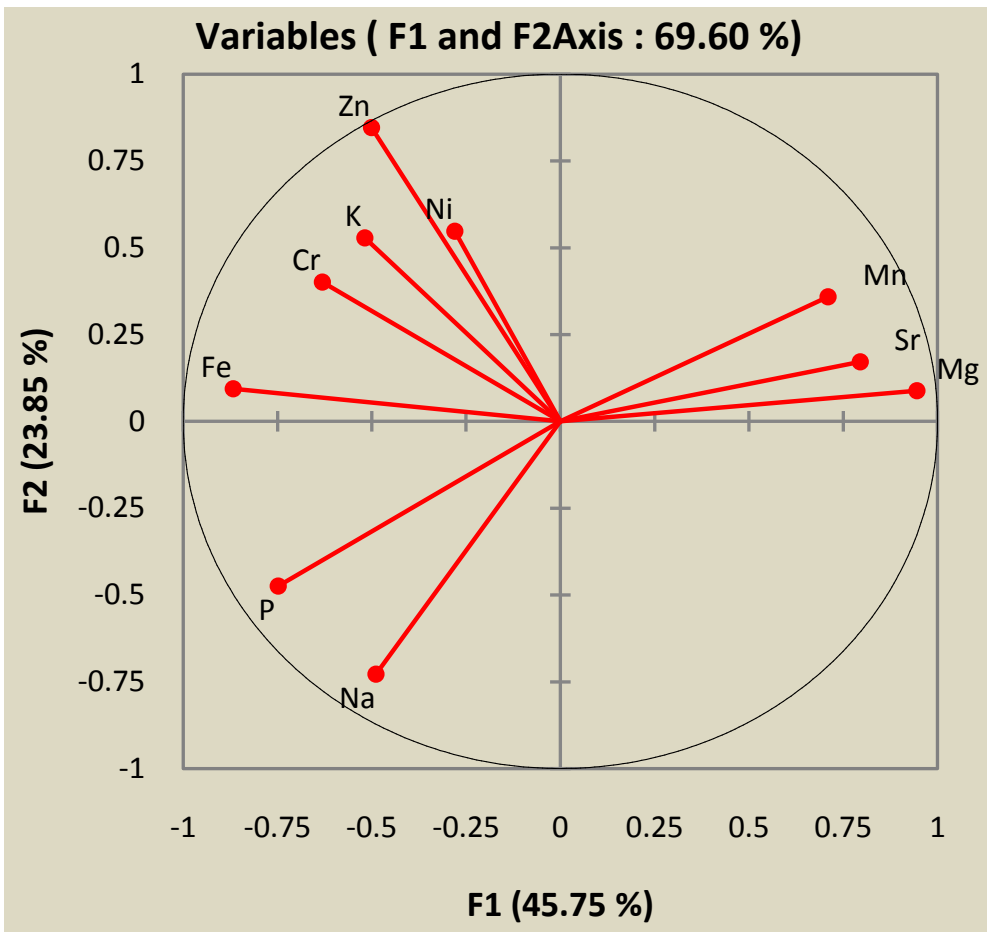

Figure 9. Correlation circle of variables.

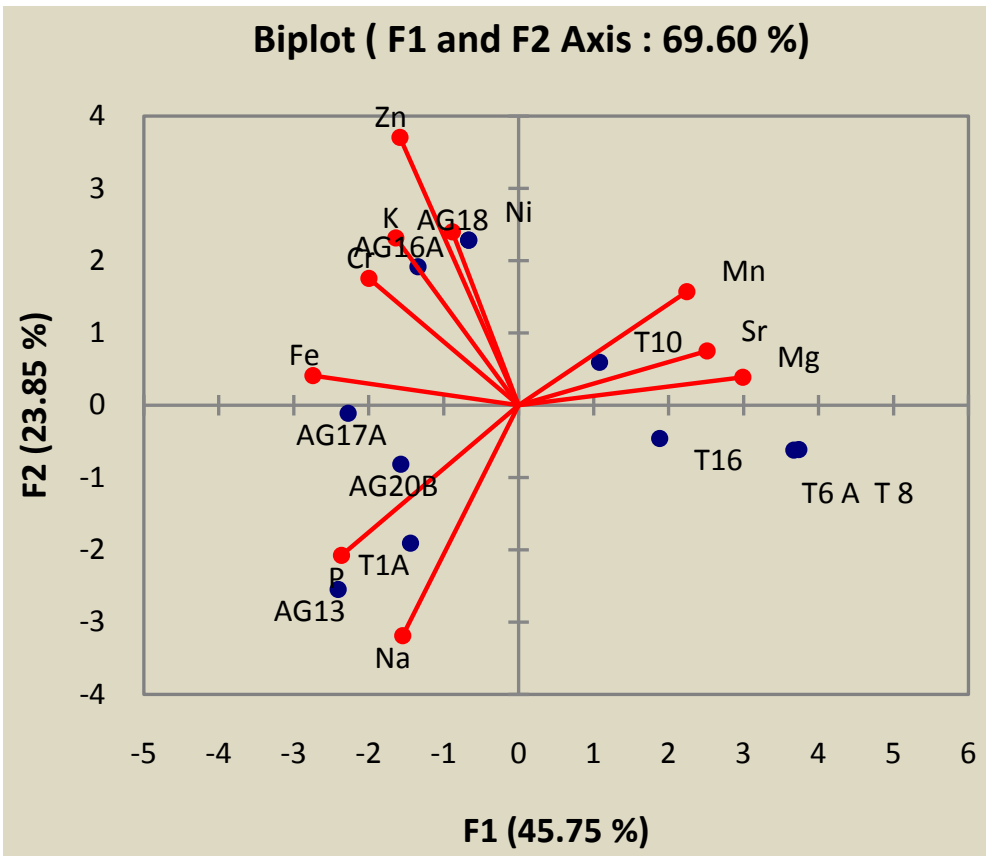

Figure 10. Affinities between samples and chemical elements analyzed.

\section{Conclusions}

The Tassemakt facies are structured into four depositional sequences and a single sedimentary cortege with a transgressive regime. These sequences are arranged on the three formations in this section (El Koubbat, Irbzer and BekritTimahdite Formations). During the Maastrichtian, bituminous facies reflect a 
subsident marine environment evolving to a more open and oxidizing environment at the end of the second sequence.

The results of the study of organic matter [31] [32] associated with the sedimentological setting, lead us to consider that the organic matter-phosphate/ oil shale relationship is linked to a closed threshold paleogeographic system. The emplacement of the phosphate and bituminous deposits occurred in tilted block basins which underlines the importance of the Northern Middle Atlas Fault, the Southern Middle Atlas Accident and their adjacent structures. The play of faults and their associated structures delineated compartments and paleogeographic motifs in thresholds that played a determining role in the establishment of the phosphate and bituminous corteges.

The paleogeographic and geodynamic setting explains the difference between phosphate and bituminous sedimentation in the other phosphate basins of the Middle Atlas [2] [31] [32] [65]. It can be said that organic matter phosphate is conditioned by a redox oxidation potential with regard to bituminous sedimentation, which is probably linked to the closure of the paleogeographic conditions [12]. They suggested a stratification of the water taking into account the hydrogen peroxide and the minimum oxygen layer $\left(\mathrm{O}_{2} / \mathrm{O}_{2}\right.$ minimum) as a favorable zone for phosphate and the minimum oxygen zone as a favorable zone for bituminous deposits.

On the other hand, the Paleocene bears witness to a proximal marine environment with several continental episodes. The presence of woody organic matter and gymnosperms spores testify to a certain humidity of the climate and the proximity of the continent to the sedimentation environment.

The Eocene area marks the beginning of the installation of a carbonate barrier platform. The study of Eocene microfacies revealed a recurrence of high energy and low energy barrier zone media from the supratidal zone. These microfacies families are characterized by a more diversified faunal association (Bryozoans, Crinoids, Gastropods...). On the other hand, the geochemical study revealed several correlations, the most striking being the positive correlation of Magnesium; Strontium and Manganese.

\section{Acknowledgements}

We would like to sincerely thank the members of the Sedimentary Basins Dynamics and Geological Correlations Laboratory, Department of Geology, Faculty of Science Ben M'Sik for their field assistance and valuable discussions. We also thank the reviewers and editors of this journal for their constructive criticism and comments on the paper.

\section{Conflicts of Interest}

The authors declare no conflicts of interest regarding the publication of this paper.

\section{References}

[1] Herbig, H.G. (1991) Das Paläogen am Südrand des zentralen Hohen Atlas und im 
Mittleren Atlas Marrokkos. Stratigraphie, Fazies, Paläeogeographue und Paläotecktonik. Berliner geowiss. Abh, (A). 135-289.

[2] Ait Sliman, M.A. (2004) Le Paléogène du Moyen Atlas: Analyse, évolution et cadre géodynamique. Thèse d'état, Université Hassan II Mohammedia, Casablanca, 332.

[3] Fedan, B. (1988) Evolution géodynamique d'un bassin intraplaque sur décrochements: Le Moyen Atlas (Maroc) durant le Méso-Cénozoïque. Thèse Doctorat d'Etat, Univ. Mohammed V, Rabat, 338.

[4] Charrière, A. (1990) Héritage hercynien et évolution géodynamique alpine d'une chaine intracontinentale: Le Moyen Atlas au SE de Fès (Maroc). Thèse d'état, Université Paul Sabatier, Toulouse III (Sciences), 2 tomes, 589.

[5] Charroud, M. (1990). Evolution géodynamique de la partie sud-ouest du Moyen Atlas durant le passage Jurassique Crétacé, le Crétacé et le Paléogène. Thèse 3ème cycle, Université Mohammed V, Rabat, 232.

[6] Laadila, M. (1996). Stades de l'évolution de la plataforme carbonatée liasique du Moyen Atlas (Maroc). Thèse Doctorat d'Etat, Univ. Mohammed V, Rabat, 442.

[7] Ouarhache, D., Charriere, A., Chalot-Prat, F. and El-Wartiti, M. (2000) Late Triassic to Infra-Liassic Continental Detrital Sedimentation Synchronous with an Explosive Volcanic Event in the Atlas Area [High Moulouya, Morocco]. Journal of African Earth Sciences, 31, 555-570. https://doi.org/10.1016/S0899-5362(00)80007-X

[8] Juidette, M. (2000) Les épisodes carbonatés méso-cénozoïques du Moyen Atlas et de la haute Moulouya: Sédimentogenèse, Diagenèse polyphasée et contexte dynamique. Thèse de 3ème cycle, Univ. Mohammed V, Rabat, 232.

[9] Nassili, M. (2006) Evolution Géodynamique comparée des séries jurassiques (LiasDogger) du pourtour du bassin de Guercif (Moyen Atlas, Hauts Plateaux et zone de Taourirt-Maroc nord oriental). Thèse Doctorat d'Etat es-sciences naturelles, Univ. Mohammed V, Rabat, 309.

[10] Ouarhache, D., Charriere, A., Chalot-Prat, F. and Wartiti, M. (2012) Triassic to Early Liassic Continental Rifting Chronology and Process at the Southwest Margin of the Alpine Tethys (Middle Atlas and High Moulouya, Morocco); Correlations with the Atlantic Rifting, Synchronous and Diachronous. Bulletin de la Société Géologique de France, 183, 233-249. https://doi.org/10.2113/gssgfbull.183.3.233

[11] Oukassou, M., Charrière, A., Lagnaoui, A., Gibb, S., Michard, A. and Saddiqi, O. (2016) First Occurrence of the Ichnogenus Selenichnites from the Middle Jurassic Strata of the Skoura Syncline (Middle Atlas, Morocco); Palaeoecological and Palaeoenvironmental Context. Comptes Rendus Palevol, 15, 461-471. https://doi.org/10.1016/j.crpv.2015.09.013

[12] Chakir, S., Slimani, H., Hssaida,T., Kocsis, L., Gheerbrant, E., Bardet, N., Jalil, N.E., Mouflih, M., Mahboub, I. and Jbari, H. (2019) Dinoflagellate Cyst Evidence for the Age, Palaeoenvironment and Paleoclimate of a New Cretaceouse Paleogene (K/Pg) Boundary Section at the Bou Angueur Syncline, Middle Atlas, Morocco. Cretaceous Research, 106, Article ID: 104219. https://doi.org/10.1016/j.cretres.2019.104219

[13] Aubry, M.P., Ouda, K., Dupuis, C., Berggren, W.A. and Vancouvering, J.A. (2007) The Global Standard-Section and Point (GSSP) for the Base of the Eocene Series in the Dababya Section (Egypt). Episodes, 30, 271-286.

https://doi.org/10.18814/epiiugs/2007/v30i4/003

[14] Colin, J.P., Tambareau, Y. and Krasheninnikov, V.A. (1998) Maastrichtian and Paleocene Ostracode Assemblages of Mali (Western Africa). Slovenska Akademija Znanosti in Umetnosti, 34, 273-345. 
[15] Guernet, C. and Danelian, T. (2006) Ostracodes bathyaux du Crétacé terminalÉocène moyen en Atlantique tropical (Plateau de Demerara, Leg 207). Revue de micropaléontologie, 49, 215-225. https://doi.org/10.1016/j.revmic.2006.10.005

[16] Aumond, G., Kochhann, K.G.D., Florisbal, L.S., Fauth, S.B., Bergue, C.T. and Fauth, G. (2009) Maastrichtian-Early Danian Radiolarians and Ostracodes from ODP Site 1001b, Caribbean Sea. Revista Brasileira de Paleontologia, 12, 195-210. https://doi.org/10.4072/rbp.2009.3.03

[17] Adatte, T., Keller, G., Schoene, B. and Khadri, S. (2015) Timing, Tempo and Paleoenvironmental Influence of Deccan Volcanism Relative to the KT Extinction. EGU General Assembly Conference, Abstracts 17, Vienna, 12-17 April, 5372.

[18] Kocsis, L., Gheerbrant, E., Mouflih, M., Cappetta, H., Ulianov, A., Chiaradia, M. and Bardet, N. (2016) Gradual Oxygenation of Upwelled Seawater from the Late Cretaceous through Early Paleogene at the Northwest Coast of Africa. Chemical Geology, 421, 44-54. https://doi.org/10.1016/j.chemgeo.2015.12.001

[19] Zachos, J.C., Dickens, G.R. and Zeebe, R.E. (2008) An Early Cenozoic Perspective on Greenhouse Warming and Carbon-Cycle Dynamics. Nature, 451, 279-283. https://doi.org/10.1038/nature06588

[20] Murphy, B.H., Farley, K.A. and Zachos, J.C. (2010) An Extraterrestrial 3 He-Based Timescale for the Paleocene-Eocene Thermal Maximum (PETM) from Walvis Ridge, IODP Site 1266. Geochimica et Cosmochimica Acta, 74, 5098-5108. https://doi.org/10.1016/j.gca.2010.03.039

[21] Charles, A.J., Condon, D.J., Harding, I.C., Pälike, H., Marshall, J.E., Cui, Y., Kump, L. and Croudace, I.W. (2011) Constraints on the Numerical Age of the Paleocene-Eocene Boundary. Geochemistry, Geophysics, Geosystems, 12, Q0AA17. https://doi.org/10.1029/2010GC003426

[22] Aubry, M.P. and Salem, R. (2012) The Dababiya Core: A Window into Paleocene to Early Eocene Depositional History in Egypt Based on Coccolith Stratigraphy. Stratigraphy, 9, 287-346.

[23] Renne, P.R., Deino, A.L., Hilgen, F.J., Kuiper, K.F., Mark, D.F., Mitchell, W.S. and Smit, J. (2013) Time Scales of Critical Events around the Cretaceous-Paleogene Boundary. Science, 339, 684-687. https://doi.org/10.1126/science.1230492

[24] Faris, M. and Farouk, S. (2015) Calcareous Nannofossils of the Paleocene Eocene Transition in Four Sections from Egypt. Turkish Journal of Earth Sciences, 24, 585606. https://doi.org/10.3906/yer-1411-25

[25] Chellaï, E.H., Marzoqi, M., Mouflih, M. and Pascal, A. (1993) Paleogene Deposits of Meseta and Hiegh Atlas (near Marrakesh): Tidal Flats, Shalow Marine Carbonates in Platform Ramp and Sea Level Control. 14th Regional Meeting of Sedimentology Marrakech, Field-Trip Guidebook, Excursion, A6, 78-109.

[26] Chellai, E.H., Marzoqi, M., Pascal, A. and Mouflih, M. (1995) Evolution séquentielle et dynamique des corps sédimentaires fini-crétacés/paléogènes du Haut-Atlas de Marrakech (Maroc). Comptes Rendus de P Académie des Sciences, 321, 747-752.

[27] Marzoqi, M. (2001) Les systèmes sédimentaires marins du crétacé terminal paléogène dans l'Atlas de Marrakech et le bassin de Ouarzazate: Sédimentologie, Stratigraphie et Paléoenvironnements-Rapport avec la tectonique et les variations du niveau marin. Thèse Doctorat d'Etat, Univ. Cadi Ayyad, Marrakech, 412.

[28] Mouflih, M. (1991) La série phosphatée du gisement de Benguerir séquences de faciès, évolution séquentielle, minéralogie et géochimie (Maastrichtien-lutétien). Thèse de 3ème cycle, Univ. Cadi Ayyad, Marrakech, 246. 
[29] Mouflih, M., Chellai, E.H. and Pascal, A. (2000) Les cortèges sédimentaires finicrétaces/paléogènes du bassin phosphaté des Oulad Abdoun (Maroc): Evolution et Implication paléogéographique. 18ème Réunion des Sciences de la terre, RST 2000, Paris, 17 au 20 Avril, 57-61.

[30] Mouflih, M., Chellai, E.H., Samih, A., Pascal, A., Sebti, S., Bouya, B., Amaghzaz, M. and Mchichi, M. (2004) Evolution séquentielle et dynamique des corps sédimentaires finicrétacés et palèogènes du bassin phosphaté des Oulad Abdoun (Maroc). The First Conference on the Valorisation of Phosphates and Phosphorous Compounds, COVAPHOS 1, Marrakech, 17.

[31] Mouflih, M. (2015) Les phosphates du Maroc central et du Moyen Atlas (Maastrichtien-Lutétien): Sédimentologie, stratigraphie séquentielle, contexte génétique et valorisation. Thèse Doctorat d'Etat, Univ. Cadi Ayyad, Marrakech, 351.

[32] Mouflih, M., Samih, A., Chellai, E.H., Pascal, A., Benbouziane, A., Aklil, A., Jahroud, N., Sebti, S., Amarghzaz, M., Bouya, B. and Mchichi, M. (2006) Les Cortèges Phosphatés et Bitumineux du Moyen Atlas: Contexte Sédimentologique et Génétique. Notes et Mémoires du Service Géologique du Maroc, 514, 57-64.

[33] Choubert, G. and Marcais, J. (1952) Aperçu structural in Géologie du Maroc. XIXéme Congés Géol. Inten., Alger, 1952, monogr Rég., 3ème série, Maroc, nº, pp. 9-73, 2 cartes, Notes et Mém. Serv.Géol., Maroc, $\mathrm{n}^{\circ} 100$.

[34] Dubar, G. (1952) Livret-Guide de l'excursion A34. 19eme Cong Géol. Int., Alger, Ser. Maroc, $\mathrm{n}^{\circ} 4$.

[35] Termier, H. (1936) Etudes géologiques sur le Maroc central et le Moyen Atlas septentrional. Notes et Mém. Serv. Mines et cartes géologiques. Maroc, n 33, tome IX.

[36] Colo, G. (1961-64) Contribution à l'étude du Jurassique du Moyen Atlas septentrional. 2 volumes. Notes et Mém. Serv. Géol. Maroc, nº 139 bis, 226.

[37] Ait Sliman, M.A. (1989) Evolution structuro-sédimentaire Paléogène de la partie sud-Ouest du Moyen-Atlas (Baqrit-Timahdit-Guigou-BouAnguer-Ain Nokra-Oudiksou). D.S.S. Univérsité Cadi Ayyad, Faculté des Sciences de Marrakech, 179.

[38] Mountaj, S., Remmal, T., Lakroud, K., Boivin, P., El Hassani el Amrani, I.E., El Kamel, F., Makhoukhi, S., Jounaid, H., Amraoui, F. and Soufi, M. (2019) The Volcanic Field of the Middle Atlas Causse: Highlights and Heritage Appropriation. The Geographical Bulletin, 60, 127-147.

[39] Moukadiri, A. (1983) Les enclaves ultrabasiques associées aux basaltes alcalins dans le district volcanique d'Azrou Timahdite (Moyen Atlas, Maroc). Thèse 3èmeCycle, Clermont-Ferrand Il, 150.

[40] Harmand, C. and Cantagre, J.M. (1984) Le volcanisme alcalin tertiaire et quaternaire du Moyen atlas (Maroc): Chronologie K/Ar et cadre géodynamique. Journal of African Earth Sciences, 2, 51-55. https://doi.org/10.1016/0899-5362(84)90019-8

[41] Harmand, C. and Moukadiri, A. (1986) Synchronisme entre tectonique compressive et volcanisme alcalin: Exemple de la province quaternaire du Moyen Atlas (Maroc). Bulletin de la Société Géologique de France, 2, 595-603. https://doi.org/10.2113/gssgfbull.II.4.595

[42] El Azzouzi, M., Maury, R.C., Bellon, H., Youbi, N., Cotten, J. and Kharbouch, F. (2010) Petrology and K-Ar Chronology of the Neogene-Quaternary Middle Atlas Basaltic Province, Morocco. Bulletin de la Societe Geologique de France, 181, 243 257. https://doi.org/10.2113/gssgfbull.181.3.243

[43] Brede, R. (1992) Structural Aspect of the Middle and High Atlas (Morocco), Phenomena 
and Causalities. Geologische Rundschau, 81, 170-184. https://doi.org/10.1007/BF01764547

[44] Brede, R., Hauptman, M. and Herbig, H.G. (1992) Plate Tectonics and Intratectonic Mountain Ranges-A Model for Mesozoic-Cenozoic Development for the Central High Atlas and the Middle Atlas (Morocco). Geologische Rundschau, 81, 127-142. https://doi.org/10.1007/BF01764544

[45] Zizi, M. (2002) Triassic-Jurassic Extensional Systems and Their Neogene Reactivation in Northern Morocco; the Rides Prerifaines and Guercif Basin. Notes et Mémoires du Service Géologique du Maroc, 146, 1-138.

[46] El Arabi, H., Charriere, A., Sabaoui, A., Ouahhabi, B., Kerchaoui, S., Boutakiout, M. and Laadila, M. (1999) Le Toarcien et l'Aalenien dans le nord du Moyen-Atlas plisse (Maroc); diversite de l'enregistrement sedimentaire et reconstitution du contexte paleogeographique. Bulletin de la Société Géologique de France, 170, 629-641.

[47] Lehmann, J. and Herbig, G.H. (2009) Late cretaceous ammonites from the Bou Anguer syncline (Middle Atlas, Morocco)-Stratigraphic and palaeobiogeographic implications. Palaeontographica, Abteilung A, 289, 45-87. https://doi.org/10.1127/pala/289/2009/45

[48] Rahhali, I. (1970) Foraminifère benthoniques et pélagiques du Cretacé superieur du synclinal d'El Koubbat (Moyen Atlas). Notes et Mémoires du Service Géologique du Maroc, 30, 51-97.

[49] Mebrouk, F., Tabuce, R., Cappetta, H. and Fei, M. (2009) Charophytes du Crétacé/ Paléocène du Moyen-Atlas (Maroc): Systématique et implications biochronologiques. Revue de Micropaléontologie, 52, 131-139. https://doi.org/10.1016/j.revmic.2007.08.003

[50] Herbig, H.G. (1993) Stratigraphy, Facies, and Synsedimentary Tectonics of PostMiddle Eocene Tertiary, Middle-Atlas West of Boulemane (Morocco). Neues Jahrbuch für Geologie und Paläontologie, 188, 1-50.

[51] Schudack, M. and Herbig, H. G. (1995) Charophytes from the Cretaceous-Tertiary Boundary Beds of the Middle Atlas Mountains, Morroco. Géologie Mediterranéenne, 22, 125-139. https://doi.org/10.3406/geolm.1995.1574

[52] Flügel, E. (2010) Microfacies of Carbonate Rocks: Analysis, Interpretation and Application. Springer, Berlin, 950. https://doi.org/10.1007/978-3-642-03796-2

[53] Dunham, R.J. (1962) Classification of Carbonate Rocks According to Depositional Texture. In: Ham, W.E., Ed., Classification of Carbonate Rocks, American Association of Petroleum Geologists Memoir, 1, Tulsa, 108-121.

[54] Embry, A.F. and Klovan, J.S. (1971) A Late Devonian Reef Tract on Northeastern Banks Island, N.W.T. Bulletin of Canadian Petroleum Geology, 4, 730-781.

[55] Alberti, G. (1959) Zur Kenntnis der Gattung Deflandrea Eisenack (Dinoflag.) in der Kreideundim Alttertiär Nord-und Mitteldeutschlands. Mitteilungenausdem Geologischen Staatsinstitut in Hamburg, 28, 93-105.

[56] Lentin, J.K. and Williams, G.L. (1977) Fossil dinoflagellate genus Isabelidinium nom. nov. Palynology, 1, 167-168. https://doi.org/10.1080/01916122.1977.9989158

[57] Slimani, H., Louwye, S., Dusar, M. and Lagrou, D. (2011) Connecting the Chalk Group of the Campinen Basin to the Dinoflagellate Cyst Biostratigraphy of the Campanian to Danian in the Borehole Meer (Northern Belgium). Netherlands Journal of Geosciences, 90, 129-164. https://doi.org/10.1017/S0016774600001074

[58] Fechner, G.G. and Mohr, B. (1986) Zurtertiären Dinoflagellaten Gattung Carpatella Grigorovich 1969 (Gonyaulacystaceae). Paläontologische Zeitschrift, 60, 181-188. 
https://doi.org/10.1007/BF02985667

[59] Damassa, S.P. (1988) Carpatella cornuta Grigorovich 1969 (Dinophyceae)-a member of the Aptiana-Ventriosum Complex. Palynology, 12, 167-177. https://doi.org/10.1080/01916122.1988.9989342

[60] Slimani, H., Louwye, S. and Toufiq, A. (2010) Dinoflagellate Cysts from the Cretaceous-Palaeogene Boundary at OuledHaddou, Southeastern Rif, Morocco: Biostratigraphy, Paleoenvironments and Paleobiogeography. Palynology, 34, 90-124. https://doi.org/10.1080/01916121003629933

[61] Guédé, K.E., Slimani, H., Jean-Paul Yao, N., Chekar, M., Jean-Claude Koffi, N., M'Hamdi, A., Mouah, R. and Digbehi, B.Z. (2019) Late Cretaceous to Early Eocene Dinoflagellate Cysts from the "12 Frères" Borehole, Fresco, Southwestern Côte d'Ivoire: Biostratigraphy and Paleobiogeographic Implication. Journal of African Earth Sciences, 150, 744-756. https://doi.org/10.1016/j.jafrearsci.2018.10.003

[62] Renard, M. (1975) Etude géochimique de la fraction carbonatée d'un facies de bordure de dépôt gypseux (exemple du gypse Ludien du Bassin de Paris). Sedimentary Geology, 13, 191-231. https://doi.org/10.1016/0037-0738(75)90020-2

[63] Pascal, A. (1985) Les systèmes biosédimentaires urgoniens (Aptien-Albien) sur la marge nord-ibérique. Thèse d'état, Dijon, 561.

[64] M'rabet, A. (1981) Stratigraphie, sédimentologie et diagenèse des carbonates des séries du Crétacé inférieur de Tunisie central. Thèse d'état, Orsay, 540.

[65] Deconink, J.F. (2014) Paléoclimats: L'enregistrement sédimentaire des variations climatiques. Edition Vuibert, 234. 